\title{
Assessing the Determinants of Customer Satisfaction in Major Supermarkets in Vietnam
}

\author{
Cuong Nguyen ${ }^{1}$, Truc Doan ${ }^{1} \&$ Duy Nguyen ${ }^{1}$ \\ ${ }^{1}$ Business Faculty, FPT University, Viet Nam \\ Correspondence: Cuong Nguyen, Business Faculty, FPT University Ho Chi Minh city Campus, Viet Nam.
}

Tel: 84-968-681-023. E-mail: cuongnq17@fe.edu.vn

Received: April 26, 2018; Accepted: May 7, 2018; Published: May 18, 2018

\begin{abstract}
This study attempts to identify the determinants of customer satisfaction in major supermarkets in Vietnam. The sample size includes 250 responses collected by convenient method at supermarkets in Vietnam. The SERVQUAL model is employed and Exploratory Factors Analysis is utilised as research design. The results confirm that customer satisfaction is positively influenced by tangibility, empathy, responsiveness, assurance and reliablity. The strongest determinant of customer satisfaction is responsiveness $(\beta=0.261)$. From these findings, some recommendations for Vietnamese supermarkets to improve their customer satisfaction were proposed.
\end{abstract}

Keywords: customer satisfaction, supermarkets, Vietnam, SERVQUAL, Exploratory Factor Analysis

\section{Introduction}

In the intense competition of modern economy, customer satisfaction can be viewed as a key factor that guarantees the survival and development of a business organization. It is vital for the business organizations to consider offering what the clients need instead of offering quality products and services which may not link to the customers' desire. Furthermore, business organizations need to have a customer-driven system to fulfill their customer's expectations. Satisfying a customer not only help business organisation maintain current customers but also attract new customers. The main objective of this study is to assess the factors influencing customer satisfaction at supermarkets in Vietnam. After identifying those factors, implications from the key findings are expected to help Vietnamese supermarkets to provide outstanding customer experiences for Vietnamese customers. The study collects information from supermarkets in Ho Chi Minh city of Vietnam. The survey employed the convenience sampling technique to collect responses from supermarket's shopping customers. The findings are expected to help Vietnamese supermarkets to identify the factors that affect their customer satisfaction. Moreover, supermarkets can assess those factors to improve their customer service to maintain customer loyalty and attract more new customers in Vietnamese retailing marketing which is recently booming due to rapid economic development.

\section{Method}

Berman and Evans (2004) define that retailing includes the operating business linked to the selling goods and services to consumers for personal, their relationship, family use. Kent (2003) confirm that retailers provide the appropriate goods, create a pleasant environment, avoid shopping risks and rise shopping comfort and manage cost for reducing price with purpose of creating customer's value. According to Kotler (2000); Hoyer \& MacInnis (2001), satisfaction is a man's feelings of pleasure, excitement, delight or disappointment which comes from comparing a products perceived performance to his or her desires. Satisfaction implies the happiness one feels when one has fulfilled a desire, need or expectation. Furthermore, customer satisfaction can be a measurement of how happy clients are with the goods and services at the supermarket. Keeping clients cheerful is one of enormous advantages to organizations. Satisfied customers are more likely to maintain their loyalty, consume more as well as refer their social network to the business. Hansemark and Albinsson (2004) define that satisfaction is as a general mentality towards a supplier or an emotional response to know the distinction between what clients expect and what they really get with respect to fulfill a desire. Satisfaction is a shopper's post-purchase assessment of the overall service experience. It is an affective reaction (Menon, Dubé, 2000) in which the consumer's needs, desires and expectations during the course of the service experience have been met or exceeded (Lovelock, 2001). Ciavolino \& Dahlgaard (2007) suggested that customer satisfaction can be characterized as the overall evaluation of the service performances or use. According to Hoyer \& Macinnis (2001) satisfaction can be connected with feelings of acceptance, help, excitement and pleasure. Furthermore, Labarbera \& Mazursky (1983) say that 
satisfaction impacts on repurchase behavior while dissatisfaction is seen as an essential explanation about client surrender or suspension of purchase. Hoyer \& MacInnis (2001) also said that dissatisfied customers can choose to discontinue purchasing the goods or services and engage in negative word of mouth. The research was supported by Zairi (2000) who also implies that many studies have viewed the effect of customer satisfaction on repeat purchase, loyalty as well as maintenance. In fact, customer satisfaction now represents a central strategic focus for customer-oriented firms across diverse industries (Szymanski and Henard, 2001).

\subsection{SERVQUAL Model For Evaluation of Customer Satisfaction}

According to Parasuraman et al (1985), the higher perceived service quality increases, the more customers will satisfy. He agrees that in fact, service quality affect to customer satisfaction. The same idea as Parasuraman et al (1985), Saravana \& Rao, (2007, p.436) and Lee et al., (2000, p.226) also suggested that service quality from service supplier will decide the level of customer satisfaction. Fen \& Lian, (2005, p.59-60) acknowledged that both of service quality and customer satisfaction have decisive part to create the success or failure of any companies in market. They can still affect positively on consumer behavior such as re-purchased or return service. This research showed that there is a connection between service quality and customer satisfaction. Parasuraman et al., (1985), developed a model of service quality after carrying out a study on four service settings: retail banking, credit card services, repair and maintenance of electrical appliances, and long-distance telephone services. The SERVQUAL model represents service quality as the discrepancy between a customer's expectations of service offering and the customer's perceptions of the service received (Parasuraman et al., 1985). This makes it an attitude measure. What this model strives to measure exactly is the consumer perception of the service quality which depends on the size of the gap between expected service and perceived service which in turn, depends on the gaps under the control of the service provider such as delivery of service, marketing, (Parasuraman et al., 1985). This measurement of service quality is based on both on how consumer evaluates the service delivery process and the outcome of the service, (Parasuraman et al., 1985, p.42). A good service quality is considered as one which meets or exceeds consumer's expectation of the service (Parasuraman et al., 1985, p.46). The SERVQUAL approach is a popular model to measure the quality in service and retailing organizations (Parasuraman et al., 1988; Parasuraman et al., 1991). The quality of service mentions about the pre-purchased of customers, their expectation before using service, customers' perceived quality during process, and their post purchased perceiving. Parasuraman et al. (1988) determined the service quality is the difference between what customers expect from service in pre-purchased step and what their perception after gaining service experience is. According to Parasuraman et al. (1985), we would like to measure the service quality; this model was created with ten dimensions which are tangibles, reliability, responsiveness, communication, credibility, security, competence, courtesy, understanding the customer, and access. Parasuraman et al. (1988) due to the changing and adaptation, there are some items like: communication, competence, credibility, security, courtesy, understanding customers, and access become no longer useful. With the new changing, in the SERQUAL model there are 22 items in basic SERVQUAL instrument. Those 22 components were arranged and put into five main dimensions which are tangibles, reliability, responsiveness, assurance, and empathy. A brief definition about these dimensions, in the tangibles scale, they measure physical facilities, devices, and staff appearance. Reliability applies for measuring the performance of service, if they serve people dependably, accurately or not. Responsiveness is about the willingness of employees to help customers and provide service properly, quickly. Assurance part encompasses the employee's abilities and attitude such as knowledge, courtesy, ability to create trust and confidence. Final scale is empathy which point out the attention of the firm and if they provides the caring and consideration for their customers (Parasuraman et al., 1988, p.23). The customer's expectations are the external components but that factors can be controlled by service provider. On the diagram, the gap 5 represents the distance from customers' expectations to customers' perceptions which related to perceived service quality (Kumar et al., 2009, p.214). 


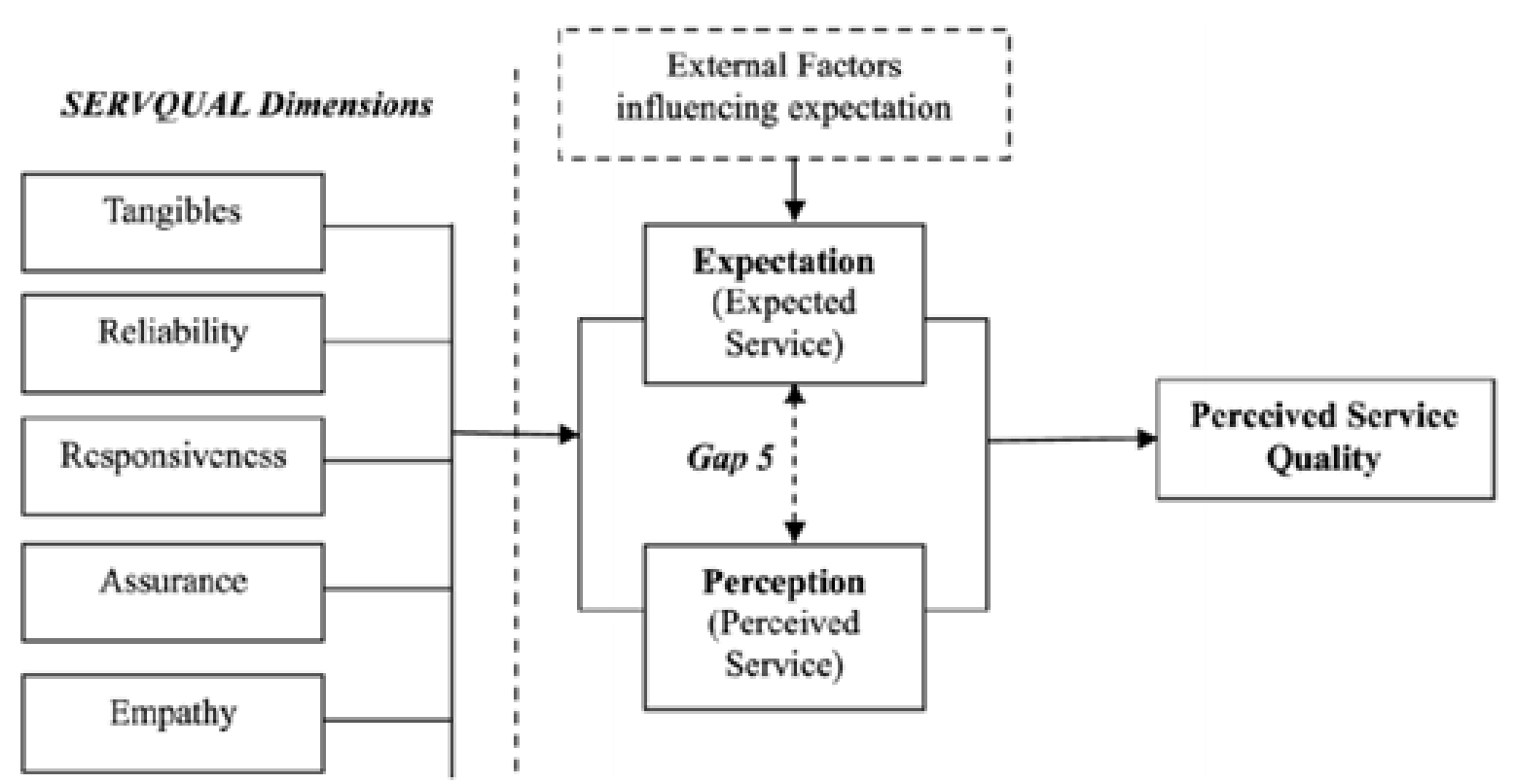

Figure 1. Measuring service quality using SERVQUAL model (Kumar et al., 2009)

Many researchers and sturdies use SERVQUAL to apply their measurement; this is the reason that this model becomes a famous and general application. Moreover, SERQUAL approach can be considered as a practical approach and it suitable for many specific situations. People tested this model for example a CPA firm (Bojanic, 1991), travel and tourism (Fick \& Ritchie 1991), hotels (Saleh \& Rylan 1991), a telephone, insurance and banks (Parasuraman et al., 1991), Hospitals (Emin Babakus, W.Glynn Mangold 1992).

\section{Results}

This research applied the SERVQUAL model of Parasuraman because it represents service quality and if the perceived service quality is positive, the customer satisfaction will be improved (Parasuraman et al., 1985). The dependent variable is defined as customer satisfaction, and there are 5 independent variables which are listed in SERVQUAL model. The Exploratory Factor Analysis (EFA) method is utilised in this study. The convenience sampling technique is used to select our respondents. The reason for selecting convenience sampling technique is because it is available in the light of easy access (Bryman \& Bell, 2007, p.197). The research process include four steps. The first step of data analysis begin with a checking Cronbach's Alpha for 22 questions in order to discover how reliable they are as well as remove unsuitable questions. In second step, Exploratory Factor Analysis is employed for the purpose of recognizing which parts can be utilized as a component of research model. The third step is to test multicollinearity between dependent variables by checking Pearson relationship. Finally, a multiple regression will keep running for dependent variable which is Customer Satisfaction and independent ones which are reliability, responsiveness, assurance, empathy, and tangibility.

\subsection{Reliability Test}

In the first step of data analysis process, a reliability test will be applied for 22 questions to check Cronbach's Alpha. Nunnally (1978); Peterson (1994); Slater (1995) all defined Cronbach's Alpha $(\alpha)$ is accepted as $0.7 \leq \alpha<$ 0.8 , is good as $0.8 \leq \alpha<0.9$ and is excellent as $\alpha \geq 0.9$. Moreover, any question has item-total correlation is less than 0.3 will be removed from questionnaire. According to the result of reliability test from SPSS, Cronbach's Alpha is 0.917 which is good, however, question number 9 has item-total correlation is less than 0.3 (0.288), which must be eliminated. For more detail, please go to Appendix 3: Reliability test of the SERVQUAL model. As a result, reliability is confirmed and 21 questions will be taken to Exploratory Factor Analysis.

\subsection{Exploratory Factor Analysis}

After checking the reliability, Exploratory Factor Analysis will be run by SPSS. According to Gerbing (1988), any questions has factor loading is less than 0.5 will be removed. Moreover, Hair J (1995); Tabachnick BG (2007) also define the KMO index, in particular, is recommended when the cases to variable ratio are less than 1:5. The KMO index ranges from 0 to 1 , with 0.50 considered suitable for factor analysis. The Bartlett's Test of Sphericity should 
be significant $(\mathrm{p}<.05)$ for factor analysis to be suitable. 21 variables are tested with Kaiser-Meyer-Olkin (KMO) and the Bartlett's test of Sphericity. Results of the KMO and Bartlett's test are shown in Table 4.6.

Table 1. The first KMO and Bartlett's Test

\begin{tabular}{lll}
\hline Kaiser-Meyer-Olkin Measure of Sampling Adequacy. & .908 \\
\hline Bartlett's Test of Sphericity & Approx. Chi-Square & 2479.114 \\
& Df & 210 \\
& Sig. & .000 \\
\hline
\end{tabular}

The KMO result is 0.908 . This indicates good partial correlation exhibited in the data for this study. The Bartlett's test of Sphericity result is 0.000 which means very significant, which means it is appropriate to apply Exploratory Factor Analysis for 21 questions.

In the first Exploratory Factor Analysis, there are 20 variables of SERVQUAL model sharing factor have loading value higher than 0.50 as shown in Appendix 3. Therefore, these values indicate that they are highly interrelated with each other. However, the question number 1 with factor loading is less than 0.5 which must be removed. The rest of the questions will be run by Exploratory Factor Analysis again.

After eliminating question number 1, there are 20 questions left will be applied Exploratory Factor Analysis. 20 variables are tested with Kaiser-Meyer-Olkin (KMO) and the Bartlett's test of Sphericity. Results of the KMO and Bartlett's test are shown in Table 4.7.

Table 2. The second KMO and Bartlett's Test

\begin{tabular}{lll}
\hline Kaiser-Meyer-Olkin Measure of Sampling Adequacy. & .907 \\
\hline Bartlett's Test of Sphericity & Approx. Chi-Square & 2411.679 \\
& Df & 190 \\
& Sig. & .000 \\
\hline
\end{tabular}

The KMO result is 0.907 . This indicates strong partial correlation exhibited in the data for this study. The Bartlett's test of Sphericity result is 0.000 which means very significant. These two data point the appropriateness to apply Exploratory Factor Analysis for 20 questions.

For the second time Exploratory Factor Analysis applied, all variables of knowledge preserving factor have loading value higher than 0.50 as shown in Appendix 3. It means these values indicate that they are highly interrelated with each other. According to Rotated Component Matrix, component 1 includes question 7, 8, and 10 which belong to Reliability in the questionnaire, so their factor name is reliability. Component 2 includes question 11, 12,13 , and 14 which belong to Responsiveness in the questionnaire, so their factor name will be perceived be responsiveness. Component 3 includes question 15, 16, 17, and 18 which belong to Assurance in the questionnaire, so their factor name is assurance. Question 19, 20, 21, 22 and 23 which belong to Empathy in the questionnaire will be taken in an account for the component 4 , so their factor name is empathy. The last component includes question 24, 25, 26 and 27 which belong to Tangibility in the questionnaire so their factor name is tangibility.

\subsection{Multicollinearity Test}

If the Pearson correlation is +1 , this means that factors have a perfect correlation. And it equals -1 , the case shows that the anti-correlation together. With the value between -1 and 1 , it shows the degree of correlation. As it run to zero, their relationship decrease from nearly uncorrelated to uncorrelated. As a result of running Exploratory Factor Analysis, there are 5 components have been created which are Tangibility, Empathy, Responsiveness, Assurance and Reliability. These 5 factors are independent variables and toward the dependent variable which called Customer Satisfaction. To move to multiple regression, Multi-collinearity test have to be done by testing the Pearson Correlation between independent variables. According to Appendix 4: The correlation between Customer satisfaction, Tangibility, Empathy, Responsiveness, Assurance and Reliability. At result of the Appendix, the Pearson correlation in 5 independent variables is 0.000 and the sig. (2-tailed) is 1.000 for all. This correlation matrix compares 5 components by each one together. This means that 5 factors are totally independent. So, there is no Multi-collinearity between 5 independent variables such as: Tangibility, Empathy, Responsiveness, 
Assurance and Reliability. In general, all of these factors have full conditions and suitable features so that they can be put into Multiple Regression.

\subsection{Multiple Regressions}

The basic multiple regression equation (Gillbert A. Churlchil Jr., 2010)

$$
\mathrm{Y}=\alpha+\beta 1 X 1+\beta 2 X 2+\cdots \beta n X N+\varepsilon
$$

The Multiple Regression method gives out the relationship between Customer Satisfaction as the dependent variable and Tangibility, Empathy, Responsiveness, Assurance and Reliability as independent variables.

\section{Customer Satisfaction $=\beta 0+\beta 1 *$ TANG $+\beta 2 *$ EMP $+\beta 3 *$ RES $+\beta 4 *$ ASSU $+\beta 5 *$ REL}

The most important step in this method is to define that the fitness of model for this multiple regression method. Following Model Summary in Appendix 4, the Adjusted R Square $=0.676$ and less than R Square $=0.683$. This result presents that this multiple regression suitable with the data and the percentage of variance which can be illuminated in this data is $68.3 \%$. As a final result, the relationship between Customer Satisfaction and Tangibility, Empathy, Responsiveness, Assurance and Reliability is illustrated as the following equation:

$$
\text { CUSSAT }=3.354+0.233 * \text { TANG }+0.233 * \text { EMP }+0.261 * \text { RES }+0.177 * \text { ASSU }+0.163 * \text { REL }
$$

\section{Conclusion and Implications}

After analyzing 5 factors influencing customer satisfaction at major Vietnamese supermarket, this report will recommend for supermarkets so that they can improve their customer satisfaction. Before moving to detail with these 5 factors, we will consider the general recommendation. In the equation of factors influencing customer satisfaction:

\section{Customer Satisfaction=3.354 + 0.233(Tangibility) +0.233 (Empathy $)+0.261($ Responsiveness $)+$ 0.177(Assurance) + 0.163(Reliability).}

We can see the responsiveness have higher influence than the others which is 0.261 and the lowest is Reliability with 0.163. So, the result mean when Supermarket focus on Responsiveness factor, the customer satisfaction will increase effectively. Researcher recommends that supermarkets should improve their service with the priority of factors below. Responsiveness is the most important factor that supermarkets should change first because when increase Responsiveness in 1 unit, the customer satisfaction will upgrade 0.261 units. To increase Responsiveness, we have 3 main points that supermarkets have to focus: service speed, sensitive to customer's interest and awareness of the moving in the target customers' common need. In order to reach these 3 points, supermarkets should develop their staffs, they have to train for employees that what the key things are in customer service by making them feel the value in serving well their customer and explain the important role of professional performance in job. In order to training staff, the professional training and recruiting system are the main things. By doing this the service speed will be improved dramatically. That will lead the employees have the abilities and willing to provide the professional performance.

Secondly, Tangibility is also should be noticed by Supermarket because the customer satisfaction increase 0.233 unit by improve tangibility 1 unit. With new equipment, supermarket will lead the feeling of customer more comfortable when shopping at mall. Researchers recommend that they need to develop their equipment and keep improve the tangibility fluently. Moreover, they should maintain the furniture because it will be depreciating dramatically with the Vietnam environment. Especially, we think they should have some value adding tools in attractive design. For example, they may design paper package instead of plastic bag and encourage customers buy it with cheap price. Through doing this, they will show how they care, protect environment and make differentiation. Make sure that quality of paper package is the most important. The longer customers use paper, package, the better result supermarkets can get. A periodic inspection for equipment is necessary for activity and it should be implemented by a specific plan.

At the same effect level with tangibility, Empathy change by 1-unit lead to 0.233 units moving in customer satisfaction. The empathy of customer is the external factors and the firm should make customer feel that company pay attention in their experience. Supermarkets must prove that they notice about customers. It means the staffs should pay more value in their performance and serve buyers in honest way. Supermarkets can establish automatic system about customer's birthday. For example, customer was born in that months, when using member card, automatic system will discount $10 \%$ on total bills. Moreover, let's their customer talk is also the positive way to apply. Supermarket should make many feedback events for their customers by using email, phone surveys; have their representatives make the interaction by asking for the customer satisfaction. For instance, they encourage their customers make feedback by giving a small gift or anyone who has a special advice or suggestion, will receive 
special promotions. They organize this event each 6 months. By doing it, the customer will feel the mall care more about them which will increase the Empathy factors. In addition, Supermarket have to show that they understand customers' need and provide the suitable condition for customer.

Assurance although cover only 0.177 unit changing in customer satisfaction, it is also the factor need to be taken care. The staffs should create the belief in customers' mind. To do this the employees have to always be kind with customer, and know enough information to adapt customer's question so that they feel safety when spending the service. In addition, the safety in transaction will contribute a large effect to this factor. We suggest that customer service question answer any questions that a client may have relating to goods and services recall. The frequenly asked questions (FAQs) should provide important information on how to determine whether the best price of that product as well as their promotion event, give detailed instructions on how to respond to a recall; provide detailed specific instructions on what precautions to take to prevent such as losing cash from thieves and how to return or replace goods when customers need. A well-trained customer service script can give impacted consumers' confidence that the recalling Supermarket is committed to solve problems while putting the needs of their customers first. These scripts can be programmed to run 24 hours a day, 7 days a week, providing instant responses to most routine or frequently asked questions from clients. Q\&A section can be used to provide consumers with information in a number of ways: free telephone number; supermarket's homepage, through emails or social media responses to customers; or direct mail. The service provider has to create the freedom feeling when buyer purchase in mall.

Reliability has lowest indicator of correlation with customer satisfaction, Supermarket should not forget this factor. The recommendation is maintaining the available products when customers need to buy, keep the professional process which lead to the positive feeling when customer make transaction. The exactly in information record can help the buyer control their need easier, when everything had been recorded, it will available when customer need it. Supermarkets should make their shipment more propitious. We suggest that customers should know about shipping process. For example, supermarkets can develop a shipping application on smartphone. Every bill was delivered, customers receive a code. They add this code to application; they will follow shipping procedure such as: where their bill and goods are, when their bill and goods will come, etc. Customers will feel secure and arrange their time to wait at home for receiving. Besides that, customers can give feedback about shipper's attitude, time for receiving goods, etc. From that, not only customers can satisfy about shipping, but also supermarkets can manage shipping goods and their shippers.

\section{Acknowledgments}

Authors declare there is no conflict of interest in this paper. Authors have no research funding for this paper.

\section{References}

Akan, P. (1995). Dimensions of service quality: a study in Istanbul. Managing Service Quality: An International Journal, 5(6), 39-43. https://doi.org/10.1108/09604529510796575

Babakus, E., \& Mangold, W. G. (1992). Adapting the SERVQUAL scale to hospital services: an empirical investigation. Health Services Research, 26(6), p.767.

Berman, B., \& Evans, J. R. (1979). Retail management: A strategic approach. New York: Macmillan.

Brady, M. K., \& Cronin Jr, J. J. (2001). Some new thoughts on conceptualizing perceived service quality: a hierarchical approach. Journal of Marketing, 65(3), 34-49. https://doi.org/10.1509/jmkg.65.3.34.18334

Bryman, A., \& Bell, E. (2007). Business research strategies. Business research methods.

Churchill, G. A., \& Iacobucci, D. (2010). Marketing research: methodological foundations.

Ciavolino, E., \& Dahlgaard, J. J. (2007). ECSI-customer satisfaction modelling and analysis: a case study. Total Quality Management, 18(5), 545-554. https://doi.org/10.1080/14783360701240337

Comrey, A. L., \& Lee, H. B. (1992). A first course in factor analysis. Hillsdale, NJ: Erlbaum.

Cronin Jr, J. J., \& Taylor, S. A. (1992). Measuring service quality: a reexamination and extension. The journal of marketing, 55-68. https://doi.org/10.2307/1252296

Dabholkar, P. A., Thorpe, D. I., \& Rentz, J. O. (1995). A measure of service quality for retail stores: scale development and validation. Journal of the Academy of marketing Science, 24(1), 3-16. https://doi.org/10.1007/BF02893933

Douglas, L., \& Connor, R. (2003). Attitudes to service quality-the expectation gap. Nutrition \& Food Science, 33(4), 165-172. https://doi.org/10.1108/00346650310488516 
Gerbing, D. W., \& Anderson, J. C. (1988). An updated paradigm for scale development incorporating unidimensionality and its assessment. Journal of Marketing Research, 186-192. https://doi.org/10.2307/3172650

Grönroos, C. (1984). A service quality model and its marketing implications. European, Journal of Marketing, 18(4), 36-44. https://doi.org/10.1108/EUM0000000004784

Hair, J. F., Black, W. C., Babin, B. J., Anderson, R. E., \& Tatham, R. L. (2006). Multivariate data analysis (Vol. 6). Upper Saddle River, NJ: Pearson Prentice Hall.

Hansemark, O. C., \& Albinsson, M. (2004). Customer satisfaction and retention: The experiences of individual employees. Managing Service Quality: An International Journal, 14(1), 40-57. https://doi.org/10.1108/09604520410513668

Hill, N., \& Alexander, J. (2000). Handbook of customer satisfaction and loyalty measurement. Gower Publishing, Ltd..

Kent, T., \& Omar, O. (2003). Retailing. Palgrave Macmillan. https://doi.org/10.1007/978-0-230-37410-2

Kotler, P., \& Keller, K. (2011). Marketing management 14th edition. Prentice Hall.

Kumar, M., Tat Kee, F., \& Taap Manshor, A. (2009). Determining the relative importance of critical factors in delivering service quality of banks: An application of dominance analysis in SERVQUAL model. Managing Service Quality: An International Journal, 19(2), 211-228. https://doi.org/10.1108/09604520910943198

LaBarbera, P. A., \& Mazursky, D. (1983). A longitudinal assessment of consumer satisfaction/dissatisfaction: the dynamic aspect of the cognitive process. Journal of Marketing Research, 393-404. https://doi.org/10.2307/3151443

Lee, H., Lee, Y., \& Yoo, D. (2000). The determinants of perceived service quality and its relationship with satisfaction. Journal of Services Marketing, 14(3), 217-231. https://doi.org/10.1108/08876040010327220

Lewis, B. R. (1993). Service quality measurement. Marketing Intelligence \& Planning, 11(4), 4-12. https://doi.org/10.1108/02634509310044199

Lovelock, C. L., Walker, R. H., \& Patterson, P. G. (2001). Services marketing: an Asia-Pacific perspective.

Menon, K., \& Dubé, L. (2000). Ensuring greater satisfaction by engineering salesperson response to customer emotions. Journal of Retailing, 76(3), 285-307. https://doi.org/10.1016/S0022-4359(00)00034-8

Negi, R. (2009). Determining Customer Satisfaction Through Perceived Service Quality: A Study of Ethiopian Mobile Users. International Journal of Mobile Marketing, 4(1).

Nunnally, J. (1978). C.(1978). Psychometric theory.

Oliver, R. L. (1980). A cognitive model of the antecedents and consequences of satisfaction decisions. Journal of Marketing Research, 460-469. https://doi.org/10.2307/3150499

Parasuraman, A., Zeithaml, V. A., \& Berry, L. L. (1985). A conceptual model of service quality and its implications for future research. Journal of Marketing, 41-50. https://doi.org/10.2307/1251430

Parasuraman, A., Zeithaml, V., \& Berry, L. (2002). SERVQUAL: A multiple-item scale for measuring consumer perceptions of service quality. Retailing: Critical concepts, 64(1), p.140.

Peterson, R. A. (1994). A meta-analysis of Cronbach's coefficient alpha. Journal of Consumer Research, 381-391. https://doi.org/10.1086/209405

Rust, R. T., \& Oliver, R. L. (Eds. 1993). Service quality: New directions in theory and practice. Sage Publications.

Ryan, M. J., Buzas, T., \& Ramaswamy, V. (1995). Making CSM a power tool. Marketing Research, 7(3), p.10.

Saravanan, R., \& Rao, K. S. P. (2007). Measurement of service quality from the customer's perspective-an empirical study. Total Quality Management and Business Excellence, 18(4), 435-449. https://doi.org/10.1080/14783360701231872

Singh, H. (2006). The importance of customer satisfaction in relation to customer loyalty and retention. Academy of Marketing Science, 60, 193-225.

Sivadas, E., \& Baker-Prewitt, J. L. (2000). An examination of the relationship between service quality, customer satisfaction, and store loyalty.International Journal of Retail \& Distribution Management, 28(2), 73-82. https://doi.org/10.1108/09590550010315223 
Slater, S. F. (1995). Issues in conducting marketing strategy research. Journal of Strategic Marketing, 3(4), 257270. https://doi.org/10.1080/09652549500000016

Szymanski, D. M., \& Henard, D. H. (2001). Customer satisfaction: A meta-analysis of the empirical evidence. Journal of the Academy of Marketing Science, 29(1), 16-35. https://doi.org/10.1177/0092070301291002

Teas, R. K. (1993). Expectations, performance evaluation, and consumers' perceptions of quality. The Journal of Marketing, 18-34. https://doi.org/10.2307/1252216

Teas, R. K. (1994). Expectations as a comparison standard in measuring service quality: An assessment of a reassessment. The Journal of Marketing, 132-139. https://doi.org/10.2307/1252257

Wang, Y., \& Lo, H. P. (2002). Service quality, customer satisfaction and behavior intentions: Evidence from China's telecommunication industry. Info, 4(6), 50-60. https://doi.org/10.1108/14636690210453406

Yap, S. F., \& Kew, M. L. (2007). Service quality and customer satisfaction: antecedents of customer's re-patronage intentions. Sunway Academic Journal, 4, 59-73.

Zairi, M. (2000). Managing customer dissatisfaction through effective complaints management systems. The TQM magazine, 12(5), 331-337. https://doi.org/10.1108/09544780010341932

\section{Copyrights}

Copyright for this article is retained by the author(s), with first publication rights granted to the journal.

This is an open-access article distributed under the terms and conditions of the Creative Commons Attribution license (http://creativecommons.org/licenses/by/4.0/). 